\title{
Speaking of Beki Luiza Bahar: A Jewish Woman Playwright in Turkey \& Negotiating an Ambiguous Identity in the Public Sphere
}

\author{
Verda Habif ${ }^{1}$ (1)
}

'PhD Student, Istanbul University, Institute of Social Sciences, Department of Theatre Criticism and Dramaturgy, İstanbul-Turkey

\section{ORCID: V.H. 0000-0003-3399-8105}

Corresponding author / Sorumlu yazar: Verda Habif,

Istanbul University, Institute of Social Sciences, Department of Theatre Criticism and

Dramaturgy, İstanbul-Turkey

E-mail/E-posta: verdahabif@gmail.com

\section{Submitted/Başvuru: 07.10 .2021}

Revision Requested/Revizyon Talebi:

04.11.2021

Last Revision Received/Son Revizyon:

05.11.2021

Accepted/Kabul: 24.11 .2021

\section{Citation/Atıf:}

Habif, Verda. "Speaking of Beki Luiza Bahar: A Jewish Woman Playwright in Turkey \& Negotiating an Ambiguous Identity in the Public Sphere" Tiyatro Eleştirmenliği ve Dramaturji Bölümü Dergisi 33, (2021): 77-97.

https://doi.org/10.26650/jtcd. 1004225

\section{ABSTRACT}

This article focuses on Beki Luiza Bahar, the first published Turkish-Jewish woman playwright. Her oeuvre includes prose, poetry, memoir and a wide spectrum of fictional and non-fictional works. To better grasp the author's writing praxis and prove how the merging of fiction, biography, and autobiography allows her to manage the contradictory elements of her identity, the study uses an inter-textual approach relying on both fictional and non-fictional works by the author. Beki Luiza Bahar's works highlight how understanding, remembering, and speaking of one's past are interwoven with selfhood and recognition in her opinion. The present analysis moves back and forth between these ideas, attempting to understand how she negotiates her minority subjectivity while writing.

Keywords: Beki Luiza Bahar, Jewish woman playwright, biographical drama, minority subjectivity, identity 


\section{Introduction}

In 1956, 27 years after Virginia Woolf declared in her famous "Professions for Women" speech that "Killing the Angel in the House was part of the occupation of a woman writer," a Turkish Jewish woman who wrote haunted by her own phantoms got published in a magazine for the first time. Beki Luiza Bahar², enamored with pens, had spent her childhood scribbling with them on everything she could get her hands on, as she recounts in the preface to her collection of essays Ordan Burdan: Ne Kendi Tanır, Ne de Söz Edeni Vardır... (Here and There: Neither Do They Know, Nor Does Anyone Speak of Them...). Therefore, it is not at all surprising when she concludes the preface of her memoir with the testimony; "The pen can sometimes overtake the person." ${ }^{3}$ This statement comes after the candid admission that the particular piece of writing intended as an overview turned out to be a page that could easily have come from her diary. She then takes a step back and reflects for a moment, afforded by the punctuation mark "three dots," and responds to the reader and herself with the aforementioned line, which is noteworthy because it not only points to the autonomy of the writing process but also shows an immediate self-reflection. It throws the reader back from the essay to the image of a woman in a room with a pen in her hand, writing in a state of flow.

In the same vein, in "Professions for Women," Woolf describes a young woman in a bedroom with an inkpot, searching for herself after killing the "Angel" within her, the shadow of whose wings used to fall on her page as she wrote. For Woolf, this phantom embodied the Victorian idea of femininity associated with being a kind, endearing lady who had no thoughts or aspirations of her own, preferring instead to sympathize with the thoughts and desires of others. Certainly, this "Angel" had to be killed to rid herself of falsehood and be herself as a writer. But then the question immediately arises: what is 'herself'? She elaborates:

I mean, what is a woman? I assure you, I do not know. I do not believe that you know. I do not believe that anybody can know until she has expressed herself in all the arts and professions open to human skill. ${ }^{4}$

Woolf recognizably draws a link here between self-understanding, recognition and expression. By all means, the subjective and auto-referential nature of self-understanding is closely connected with others' understandings, external categorizations, identifications, and representations. Moreover, the external categorizations in question are not always mutually exclusive. As Brubaker and Cooper put it in their comprehensive article on the discourses around the term "identity" in which they discuss the relationship between identity and selfunderstanding, "In some settings, people may understand and experience themselves in terms of

1 Virginia Woolf, The Death of the Moth and Other Essays (New York: Harcourt Brace \& Company, 1942 ), 237.

2 Beki Luiza Bahar was born in 1926 and died in 2011.

3 Beki L. Bahar, Ordan Burdan: Ne Kendi Tanır Ne de Söz Edeni Vardır... (İstanbul: Gözlem, 2000), 21. All translations are mine unless stated otherwise.

4 Woolf, The Death of the Moth and Other Essays, 238. 
a grid of intersecting categories. $"$ Not to mention, if these intersections are between antagonistic discourses, practices and positions, people may experience their identities as fragmented and fractured. Expression, thus, can become a means through which the fragmented and fractured discourses, practices and positions are negotiated to construct a sense of subjectivity and claim recognition.

The present study aims to show that as a Turkish-Jewish woman who lived in times of warfare and nation-building, being situated in the intersection of several conflicting categories, identification was a constant negotiation for Bahar, and it took place in the tense space between recognition by others and defining oneself. What is more, her auto-referential writing praxis was a mediation on the way to creating a conception of selfhood via self-narration and disclosure. Indeed, her writing is a testament to her struggle with phantoms that hovered around the contradictory components of her complicated identity. Furthermore, this testimony reveals the conflicts accompanying the Turkish-Jewish subjectivity that function via cultural politics of memory, visibility, and belonging.

With that in mind, the title of Bahar's memoir, -Here and There: Neither Do They Know, Nor Does Anyone Speak of Them...- is worthy of attention. Foremost, Bahar alludes with this title to the Turkish Jewish minority's disconnectedness from its past, as she sees it. The title also suggests that historians in the broader society largely ignore this historical memory. Hence, this emphasis on knowing, remembering, and speaking of one's past shows that these deeds were undoubtedly interwoven with selfhood and recognition in her understanding.

Bahar's oeuvre comprises a wide range of fictional and non-fictional works, including prose, poetry, memoir, historical articles, and dramatic works, some of which are self-published. ${ }^{6}$ This analysis focuses on her plays, adopting an inter-textual approach as a method, resorting to both fictional and non-fictional works of the author to understand her writing praxis. ${ }^{7}$ Furthermore, as previously said, since her writing practice is auto-referential, her life story plays a significant role in this study. The following section hence, will give a general overview of her life events.

\section{A Turkish- Jewish Woman in the $20^{\text {th }}$ Century}

Born in $1926,{ }^{8}$ Bahar's lifespan coincides with a period of significant local political and social changes and international life-threatening happenings. The Ottoman Empire saw substantial

5 Rogers Brubaker and Frederick Cooper, "Beyond 'Identity"” Theory and Society 29, no. 1 (February 2000): 18.

6 Later in her life Mitos-Boyut a well known publishing house for dramatic works published four of her plays. Also, her collection of essays came out of Gözlem Yayınevi, a Jewish publishing company.

7 Likewise, inter-textuality was also a strategy used by the author in her plays. It is common to find references to her other texts in her plays. Later in the article this point will be supported by examples.

8 In her memoir Ordan Burdan: Altmıs Yılın Ardından (Here and There: In the Wake of Sixty Years), she explains how her parents registered her birth year as January $16^{\text {th }} 1927$, although she was actually born on December $16^{\text {th }}$ 1926. According to Bahar, the reason was to give her an advantage in marriage worth when she would become older since the younger the girl to be married was, the worthier she was in those times in the Jewish society. The meticulous attention she gives to details even in this first page of her memoir, where she introduces herself, is an indicator of her factual approach to defining identity through a historical perspective. Beki L. Bahar, Ordan Burdan: Altmış Yılın Ardından (İstanbul: Gözlem, 1995), 7-8. 
political, social, and geopolitical upheavals throughout the nineteenth and early twentieth century and was regularly at war from the late nineteenth century until 1923. After the Ottoman Empire collapsed, the Turkish Republic was founded, and The Treaty of Lausanne (1923) defined the limits of the Turkish nation-state, which had a population of $96 \%$ Muslims. Nationalism was fueled in the Middle East and the Balkans, and active policies were implemented to realize the idea of establishing a Jewish state in Palestine. It was a period in which all minorities sought their own identities and wanted to determine their destinies. The Turkish state enforced a process of "Turkification" on its citizens in the aftermath of the geopolitical changes and the formation of the Republic. ${ }^{9}$ In the mid-1930s, as the world witnessed the rise of Nazism, the Turkish Republic first followed a policy that embraced the Jews. However, during the Second World War, as it approached Turkish territory and genocides towards Jews took place in Turkey's neighbors, the Jewish community felt under threat and fear and experienced economic difficulties with practices such as wealth tax. With the end of World War II and the establishment of the state of Israel afterwards in 1948, many Jews emigrated from Turkey. According to Rifat Bali, Turkish Jews that stayed lived in a very restricted society, clinging to their cultural values and Jewishness as defined by Zionist ideology in communal life, while on the other hand publicly displaying eagerness to adopt the Turkification policies and take on a Turkish nationalist approach. The official approach undertaken by the Jewish Community leaders were offset by this public exterior. Nonetheless, keeping this exterior for centuries has had its share in the construction of a Turkish-Jewish identity. ${ }^{10}$

Bahar was born in Istanbul and then moved with her family to Ankara, where a smaller Jewish community surrounded her, because of her father's working situation. She went to schools where no other Jewish student was present other than her and her sister, which was very different from her environment in the Jewish School of Istanbul, which she went to in her early childhood. After graduating from T.E.D. Ankara College, she enrolled to Law School at Ankara University Faculty of Language, History and Geography, an exceptional undertaking for a Turkish-Jewish woman living in those times. In this period, she was also admitted into the military course, which was mandatory for women that went to university. She did not graduate from law school because she got married and gave birth. In an interview where she was asked if she quit university because of getting married, she expressed her regrets:

Yes, I took life too seriously. I am now married, I must look after my husband and I will have a child... My husband said, keep going if you wish. By no means! What a way of thinking at those times! Besides, this is what happens; you get married and already in the first month they wonder: "Have you got pregnant?" "11

9 Gila Hadar, “Turkey: Ottoman and Post Ottoman," Jewish Women's Archive, accessed July 6, 2021, https:// jwa.org/encyclopedia/article/turkey-ottoman-and-post-ottoman.

10 Rifat Bali, "Politics of Turkification in the Single Party Period", Swiss Society for Middle Eastern and Islamic Studies, Basel, Switzerland, 14-16 October 2004.

11 Gülriz Türkoğlu, Zeynep Kutluata, and Beki Luiza Bahar. "Türkiye`de Yahudi Olmak: Beki Bahar ile Söyleşi..” Interview. Kültür ve Siyasette Feminist Yaklaşımlar 7, 2009. 
Bahar and her family returned to Istanbul many years later. She published her first prose in the magazine Haftanin Sesi in 1958, her first poem in the Varlık Yeni Şiir Antolojisi in 1959 and her first short story in Çağdaş magazine in 1964. Her earliest play, Alabora, was performed in 1970 at the Ankara State Theater. Her essays, research papers, travel notes and poems have been published in magazines and newspapers, and some of them are self-published.

\section{A Marginalized and Ambiguous Identity}

In her memoir and interviews, it is clear that one of the major conflicts Bahar experiences is between being an individual and being a member of a society through which the individual's experiences must be mediated. As a result of this conflict, she is always torn between adopting the majority discourses built around cultural modes and her individual ideals and desires. These cultural modes are determined by her position as a Jewish woman in the society of which she is a part, and by the characteristics of that larger society. According to Beti Hayim, this arbitration is crucial in self-development and identity in minority groups:

In order to understand self-development and identity within any ethnic group, one has to consider historical, geographical and cultural context. When the group in question is a minority group in a wider culture, the interrelation of the two groups should be considered. ${ }^{12}$

Thus, Bahar's self-development is inevitably influenced by the politics of identity determined by the dynamics of this interrelation. On the other hand, her unique marginal position within the Jewish society in Turkey complicates her identification with the generic discourses of this closed, institutionalized, and politicized minority society and its relationship with the wider culture. Individually, she questions the discourses and politics related to her identity from a broader and more universal historical perspective. This is clear in her emphasis on defining the Jewish people in Turkey as "a society", rather than using the term "communion" which refers to a religious structure. ${ }^{13}$ This approach also explains that although she had an extensive and deep interest in researching Jewish history and identity and expressing her Jewishness through her work, she was only partially a part of cultural production under the roof of Jewish communal institutions. More specifically, when İzzet Bana and Selim Hubeş, two Jewish theater lovers and amateur theater-makers working within the congregational institutions, discovered her while they were looking for texts related to Judaism to perform, she had already written several plays and one of them was in the repertoire of the Turkish State Theater and they did not even know about her. ${ }^{14}$ After this chance encounter, she received commissions and wrote several plays for these theatre clubs under Jewish organizations. However, since she mostly worked alone apart from these encounters, one could say that she was a "lonely spirit" so to

12 Beti Hayim, "The Sense Of Self, Superego And Ego-Ideal In Turkish Sephardic Jewish Young Adults" (unpublished MA thesis, İstanbul: 2009), viii.

13 Sevilay Saral, "Beki L. Bahar'ın Ardından ," Mimesis 19 (March 2012): 230.

14 Uluç Esen et al., "Panel: Beki L. Bahar Tiyatrosu," ed. Ayşan Sönmez, Mimesis 19 (March 2012), 235-262. 
speak. In a panel discussion about Bahar's work that took place later in her career, a researcher, Rivka Bihar, also confirms Bahar's singularity in terms of her work:

If we evaluate her within the Turkish Jewish community, we can claim that she is the only author who does not create adapted plays, deals not only with Sephardic topics and Judaism in her plays, does not focus on translated works, and fully preserves her uniqueness. ${ }^{15}$

Of like mind, Selim Hubeş and İzzet Bana tell how amazed and impressed they were when they discovered this Jewish playwright and found out that her work was in the library of the State Theater. Hubeş points out that Bahar differs from the general population of the Jewish community in Turkey:

As for Mrs. Beki, Mrs. Beki is a person sui generis, a Sephardic Jew. First, in terms of where she lived, what she read, and what she wrote, do not think there are ten Mrs. Bekis in the Jewish Sephardic community of twenty thousand people in Istanbul. Mrs. Beki is one and only one. Her work on this subject drove us crazy. When we first saw her book, we looked at each other, surprised. A woman from the Turkish Sephardic Community wrote a book! This woman wrote a play! We went crazy. Was that possible? [...] Mrs. Beki is a wonderful lady. She is very elegant. There is nothing more to say about her, because my grandmother, for example, is not like her. Or other people's grandmothers are not like her. Her children are fortunate people; their mother has such vast knowledge. Also, that Mrs. Beki has not only lived in Istanbul may have some influence. Mrs. Beki comes from a family that has a history in Eskişehir, Edirne, and Ankara. She also has an investigative personality. ${ }^{16}$

These words infer the actors were astonished to find a Sephardic woman who had written plays that were included in the repertoire collection of the State Theatre. ${ }^{17}$ It was not common at all to speak in the public sphere as a minority, let alone being a Sephardic woman born in the early $20^{\text {th }}$ century having such a commandment of the Turkish language and who even had a university education. ${ }^{18}$

As a matter of fact, Rifat Bali explains how Turkish Jews use the Ladino word 'kayadez', meaning 'quiet' and 'low profile' in their everyday speech. It implies that they try not to live

15 Rivka Bihar et al., "Panel: Beki L. Bahar Tiyatrosu ,” ed. Ayşan Sönmez, Mimesis 19 (March 2012), $235-262$.

16 Selim Hubeş et al., "Panel: Beki L. Bahar Tiyatrosu ," ed. Ayşan Sönmez, Mimesis 19 (March 2012), $235-262$.

17 Collection of potential plays to be performed accepted by the dramaturgy department. Alabora (Capsizing) was performed by the Ankara State Theatre in 1970. Although Senyora/ Gracia Nasi (Madam/ Grasya Nasi) and Ölümsüz Kullar/ Pudu Hepa (Immortal Subjects/ Pudu Hepa) were accepted to the repertoire collection, they were never performed.

18 Ladino (Judeo-Spanish) was the predominant spoken language of the Jews until the mid-1950s. While most of the men spoke Turkish and some Hebrew, the language of women's talk was Ladino. The women's lack of understanding of the official languages, however, did not affect their ability to communicate with others because all of their neighbors knew and understood Ladino. The Jews coexisted in neighborhoods where they made up the majority. Their modest houses, which opened into common courtyards, were referred to as yahudihane by the locals and cortijo by the Jews. A massive wooden door strengthened with iron bands and secured with a vertical iron bolt guarded the courtyard's entrance. The women were able to walk from one enclosure to the next through a gap between the courtyards without having to exit onto the street. Hadar, "Turkey: Ottoman and Post Ottoman". 
a too obvious lifestyle to the general public, fearing that it would cause jealousy among the larger Turkish population. According to Bali, the only way to maintain some sense of serenity and tranquility is to stay 'invisible' in the public domain. Besides, taking a 'silent' attitude is not just a survival strategy, but it also indicates a deep mistrust of both the government and the media at the same time. Examining historical events and their debate in the public realm has provided little or no value in the past and has frequently just cemented unfavorable attitudes. ${ }^{19}$ On the contrary, Bahar speaks out through her plays and other works without shying away from expressing her point of view and discusses Jewish history and Judaism. One might say that her discourse coincides with the official discourse of the Turkish Jews who describe their existence in the Ottoman Empire and the Turkish Republic through a selective perception only highlighting the positive experiences they had to express their gratitude; therefore, it does not stand out as unique. However, a close examination shows that Bahar only relies on facts to shape her views. She articulates her gratitude to Turkey and includes the positive experiences in her historical texts, but she also considers the underlying economic reasons for this treatment, opening up a discussion of events and discourses.

All this having been said, the unique positioning of Bahar in relation to the Jewish minority society in Turkey and her work gives an insight into the multi-layered narrative of otherness in her approach. The subsequent part displays how self-disclosure becomes a result and instrument of this otherness, resulting in a politics of visibility and recognition in the public sphere of writing.

\section{Writing and Subjectivity}

Bahar's dramatic works are multi-layered, in which the author presents historical identities within a fictional narrative while incorporating autobiographical elements from her own life. The merging of fiction, biography, and autobiography allows her to deal with the contradictory elements of her identity. ${ }^{20}$ The characters who represent the fractures of the author's self, and the conflicting forces at play through which the author identifies herself, are often biographical identities. Yet, they are categorically neither biographical nor autobiographical plays. Rather,

19 Ulrike Tischler and Rifat Bali, "The Alternative Way to Come to Terms with Past. Those Who Try to Forget: Turkey's Jewish Minority," in From "Milieu de mémoire" to "Lieu de mémoire" the Cultural Memory of Istanbul in the 20th Century (München: Martin Meidenbauer, 2006), 100-110.

20 At this point, Philippe Lejeune's suggestion that the unity of the author, narrator, and the protagonist is necessary and sufficient for a book to be considered autobiographical comes to one's mind. Yet, some claim that such a union is impossible to achieve. The question is whether there is something that binds experience and consciousness with identity and politics or, at the very least, with a concept of subjectivity. For more discussion on this subject refer to Philippe Lejeune, On Autobiography, ed. Paul John Eakin, trans. Katherine Leary (Minneapolis: Univ. of Minnesota Press, 1995). 
in the introduction to these texts, she makes a special point of making a "fictional pact" the reader. An example is the statement at the beginning of Senyora/ Grasya Nasi (Madam/ Grasia Nasi): "The heroes in this historical play really lived, and the events are accurately taken. But then again, this text is a play..." 22 This pact evidently allows Bahar to reconstruct a self-ideal while reflecting on a society's shared history and collective memory. She assembles the fantasy of this idealized self by assimilating the biographical identity within her personality and inner desires. Nonetheless, her writing proves that she stands in the ambiguous zone of constantly negotiating her personal desires with existing cultural models of identity and the discourses in which they are expressed. Speaking is, in fact, the mechanism by which she avoids surrendering to the categories that would confine her existence by constantly reinterpreting her experiences. In this respect, Hülya Adak's observation that fiction is the most autobiographical form of confession relates well to Bahar's plays. Although there is no direct relationship between the author and the protagonist, Bahar's works' process is very similar to that of auto-fiction where "writing becomes an integral part of existence, a never-ending process of producing subjectivity through language." ${ }^{23}$ Only, for Bahar, it is an impossible subjectivity, for she is always in the conflicting zone of becoming the subject and object of language as a Jewish woman. As Irz1k and Parla put across, “'Speaking'women, and especially women in the public sphere, have always been torn between subjectivity and objectivity, between having the word and being owned by the word, and have had to be divided both within and against themselves." 24 This fracture is further deepened by the fact that, as a Jew in Turkey, she is a member of a diaspora society. Diaspora, a term demarcated by the complex relationship between land and dispersion, belonging and being marginalized, also makes the act of 'speaking in the public sphere' a political statement where ambiguous identities are positioned within language. This ambiguity is full of traps and potentialities that this article intends to trace within Bahar's body of work.

She wrote many plays, only some of which are examined in this article. Her plays that tackle the Jewish identity are centered on the Sephardic Jews' history and sociocultural aspects and

21 The term "fictional pact" is used here as a counterpart of the novelistic contract that Lejeune talks about. As is known, Lejeune's conception of autobiography is founded on the notion of an "autobiographical pact". The reader is offered a contract: to read the text autobiographically. This "pact" is offered only if the author's name is the same as that of the narrator or protagonist and the subtitle of the book is "Autobiography, my life, etc." If this is not the case, that is, if the author, narrator, and protagonist have different names or their identities are unknown, or if the book self-identifies as a novel, then this text offers the novelistic contract and forces the reader to read it as a novel. 'Autobiography' is thus no longer an essentialist concept, but a dimension, or in other words, a fundamental part of the literary communication process. Martina Wagner-Egelhaaf, "Autobiography/ Autofiction Across Disciplines," in Handbook of Autobiography/Autofiction, ed. Martina Wagner-Egelhaaf (Berlin: De Gruyter, 2019), 1-9.

22 Beki Luiza Bahar, Toplu Oyunlarl 1: Ölümsüz Kullar ; Senyora ; Alabora (İstanbul: Mitos Boyut Yayınları, 2005), 53.

23 Claudia Gronemann, "Autofiction," in Handbook of Autobiography/Autofiction, ed. Martina Wagner-Egelhaaf (Berlin: De Gruyter, 2019), 241-246, 245.

24 Sibel Irzık and Jale Parla, “Önsöz,” in Kadınlar Dile Düşünce: Edebiyat ve Toplumsal Cinsiyet (İstanbul: İletişim, 2020), 7-12, 9. 
relations with other religions. The other ones deal with history, memory and being a woman. This study analyzes Senyora/Gracia Nasi (Madam/Grasya Nasi), Ölümsüz Kullar/Pudu Hepa (Immortal Subjects/ Pudu Hepa), İkiyüzbininci Gece (The Two Hundred Thousandth Night) and Demokles 'in Kılıcı/ Flavius ile Demokles (Damocles'Sword/ Flavius and Damocles). These plays are about the relationships between history, conflict, identity, Jewishness, being a woman, power, culture, and society. This analyses of her plays aim to show that Bahar voices her own subjectivity in a unique, sincere and bold manner through the dynamic relationships between these concepts without avoiding entering conflicting zones. Before examining the themes that interconnect these texts with elements of her identity, this article includes extensive summaries considering that they are lesser known.

\section{The Plays: Ölümsüz Kullar/ Pudu Hepa, Senyora/ Grasya Nasi, Demokles'in Kulıcv/ Flavius ve Demokles, İkiyüzbininci Gece}

Ölümsüz Kullar/ Pudu Hepa (1973-2005) is about a Hittite Queen from the $13^{\text {th }}$ Century $\mathrm{BC}$ who was the companion of King Hattuşili the $3^{\text {rd }}$. The Hittites conceived the kingdom as belonging to the gods, with kings and queens being their representatives. Nevertheless, they were responsible for the actions they undertook during their reign. The queen had a significant role in the Hittite court and foreign diplomacy. She had her own seal, was in charge of the internal affairs of the royal palaces, and presided over the trials. In the king's absence, she had complete authority. ${ }^{25}$ Obviously, by choosing Pudu Hepa as the protagonist, Bahar intends to demonstrate the status of women among the Hittites while questioning the nature of femininity. Following register from her notes on the play is an indication of this:

The protagonist Pudu-Hepa participated in wars alongside her husband, signed the Treaty of Kadesh (1278 BC), the first peace treaty recorded in history. She made her mark on history. Is it enough for a woman to become so famous that she achieves immortality?26

According to Tunçel, in this play, the author places Pudu Hepa as an authoritative, respectable, strong-willed, ambitious, and wise woman against Haştayar, an attractive, ignorant, but also audacious woman whose only goal is to please her husband and who flaunts her femininity. The tragic conflict is based on this contrast while conveying the message that an ideal woman unifies these two modes of being. ${ }^{27}$

The play starts with news of a plague epidemic in the kingdom, while King Hattuşili is outside the palace. Pudu Hepa, who serves as regent, resorts to the historical clay tablets to find a solution. She finds out that there was a plague epidemic in the past and the reason was a sin

25 Ayşe Ulusoy Tunçel. "Beki L. Bahar'ın Oyunları ve Oyun Yazarlığı .” MíMESİS Tiyatro Çeviri/Araştırma Dergisi 13 (March 2007): 102.

26 Bahar, Toplu Oyunlart 1, 7.

27 Tunçel. "Beki L. Bahar'ın Oyunları ve Oyun Yazarlığı”, 103. 
that had been committed and had degraded the sacred institution of the family. As she struggles with the reality of the situation, a woman, Haştayar, enters the palace. Haştayar is worried since her lover does not speak to her and simply sleeps with her, so she seeks the advice of Pudu Hepa. Pudu Hepa makes out that Haştayar is actually talking about her husband, the king. This twist of fate makes her realize that she is partly to blame for her husband's infidelity. As a wife, she had treated him as a partner in ruling the kingdom and not a husband. Meanwhile, Hattuşili is killed just outside the palace because he cannot pronounce the entrance password, which is regularly changed as a precaution against the plague. Hattuşili, in reality, chooses not to recite the password on purpose, accepting responsibility for his crimes. To safeguard her husband's dignity, Pudu Hepa announces to the people that she caused the epidemic. Bahar has incorporated many historical facts about the Hittites into the play, but organized them into a fictional structure.

Another strong female protagonist of Bahar is Dona Gracia Nasi, in the play Senyora/ Grasya Nasi (1992), another biographical figure. Bahar presents Senyora as a documentary play. The play was awarded the Yunus Emre Achievement Award by the Bakırköy Municipality Theater in 1995 and has been translated into French. The play was written in honor of the $500^{\text {th }}$ anniversary of the immigration of the Marranos ${ }^{28}$ and Jews to the Turkish lands. It is about the life of the merchant Beatrice Luna de Mendes / Gracia Nasi (1510-1569), who lived in Portugal and in the Ottoman Empire after Kanuni Sultan Suleiman granted citizenship to save her from the Inquisition ${ }^{29}$, which threatened to kill her because she practiced Judaism. ${ }^{30}$

Beatrice and Brianda are the daughters of the de Luna family, who fled the Inquisition in Spain and became Marranos in Portugal. Beatrice is a young lady who is interested in her ancestors and family history and so she discreetly studies Hebrew. She cannot hold back her rage and discloses her Jewish heritage when a knight she's dating insults the Jews during their conversation one day. She ends up being indicted by the Women of Lisbon, who represent the Catholic Community. Don Francisco Mendes, the king of spices whom Beatrice once refused, saves her from incarceration in a convent by marrying her. Soon enough, Francisco Mendes makes plans to flee to Antwerp, as the country is no longer safe. In the interim, Doctor Miguez, who goes out to help the wounded of the 1538 Lisbon Earthquake, is accused of bringing misfortune to the city because of his Jewish roots and is scapegoated and lynched by the angry aggrieved. After some time, Francisco Mendes also dies because of illness. After the death of her husband Beatrice devotes herself to the Jewish cause. The family leaves Lisbon soon after, then lives in Antwerp, Venice, and Ferrera, respectively. Meanwhile, Beatrice's sister Brianda and Francisco's brother Diego get married, but Diego dies too. Diego leaves his

28 Marranos were the Jews that converted to Christianity because of the oppression in Iberia.

29 In the 15th century an edict was issued in Spain according to which the Jews would either be expelled, convert to Christianity (become Marranos) or else they would be tortured and killed at the Inquisition Courts.

30 Tunçel. "Beki L. Bahar'ın Oyunları ve Oyun Yazarlığı”, 117. 
inheritance to Beatrice, whom he used to love, to spend it on 'holy causes'. Wanting to seize the inheritance, furious Brianda reports her sister to the Venetian Inquisition. This situation puts not only Beatrice but also the whole family in a difficult position. They extricated from this challenging situation with the help of Moshe Hamon, the doctor of Kanuni Sultan Suleiman, and take refuge in the Ottoman Empire. However, this time, Brianda complains about Beatrice to Beyt-Din, the supreme judicial body of the Jews in the Ottoman Empire. The case ends in Beatrice's favor. On top of all this, Beatrice learns that the Inquisition in Anacona killed one of her most loyal men. She calls on the community to boycott Anacona Port, but they cannot show solidarity with her. The play ends with Beatrice's words expressing her disappointment. In his dissertation on Bahar's plays, Özmen interprets Senyora as follows;

Beki Bahar treats the survival struggles of Jews in Europe and Ottoman Empire from the second half of the 15th century to the end of the 16th century with her play Senyora, in the background of a series of conflicts of religion, individual-society, non-oppressive thought, spirit-emotion. She presents the reckoning remarkably. It depicts a period of almost a century in an outstanding plot, without deviating from the historical facts, with the psychosocial situations of the people. The inner conflicts of the characters about identity, religion, freethinking and integration into the society they live in are given in the background, with the influence of humanism and Renaissance movements that started to affect Europe at that time. ${ }^{31}$

Demokles'in Kllıcl/ Flavius ve Demokles (2004) is also a play based on biographical characters. Only this time, the characters are from different centuries. The play is about Flavius, who lived in the $1^{\text {st }}$ century A.D., meeting Damocles, who lived in the $4^{\text {th }}$ century B.C. in a cave where time stands still. In the introduction, Bahar gives historical background information about the characters and events. Yosef (Iosephos) Flavius comes from a family of religious officials. He was a mathematician, army leader, philosopher, and historian who lived in a time when the Roman Empire was a superpower. In 64 B.C., he was sent as part of a committee to negotiate the return of Jewish clergy who were being held as prisoners in Rome. He was able to succeed in the mission. After this accomplishment, he became a commander in the Jewish army and led the soldiers in defending Galilee against the Roman siege. However, when the Romans invaded the city, he and his soldiers had to take shelter in a cave where the soldiers were left with no other option but to surrender and so they decided to kill themselves. The Romans captured the sole survivor, Yosef. Soon after, he entered the service as a historian under the auspices of the Roman Emperor and was given the name Flavius. When the Roman army blockaded Jerusalem in 70 B.C., he was also part of the siege that famously brought down the Temple of Jerusalem, which is why the Jewish people scolded him for turning his back on his people. However, it is known that he never abandoned Judaism and, in his works, tried to show the Latin and Hellenistic world that it was a favorable religion.

31 Özmen, "Beki L. Bahar'ın Tiyatro Eserlerinde Sefarad Dünyası", 47-48. 
The second main character in the play is a court jester from the $4^{\text {th }}$ century B.C., made famous through time by the phrase "Damocles' sword". Bahar, however, sets out on a mission to correct the misinformation surrounding this story. Damocles lived in the court of Dionysus, the $1^{\text {st }}$ King of Syracuse. Legend has it that one day, Damocles told the king how wonderful and luxurious his life was. The king, wanting to show him what it was like to be in his position, made him sit on his throne with a feast before him and a sword over his head. This is the origin of the story, which is a symbol of the danger that surrounds people who are in positions of power.

There are two other characters in the play: Berenis (Berenike), a princess who is fictionalized in the play's story as being in love with Flavius, and Bannus, a philosopher who mentored Flavius when he was young. The play begins in the war's aftermath, which ends with the fall of Galilee. Flavius meets Bannus and Berenis in a cave, hoping for their help as he must make an honorable decision between life and death as his soldiers are about to commit mass suicide. Long discussions accompany his casuistry. After Bannus and Berenis leave, Flavius falls asleep, and when he awakens, he sees Damocles, who is as surprised as he is. Both are told that they will have a trial to defend themselves. Damocles is eager to correct the misunderstanding surrounding his life story and let the world know that he has no business having a sword associated with his name. Flavius wants to fix people's opinions of his actions and decisions by making his point. The scene continues with a mock trial, which the two decide to hold while waiting to prepare for their actual trial. Each defends themselves against the other, but it soon becomes clear that the actual trial is taking place in their own minds. The verdict is left to the audience as the play ends.

The last play to be examined here is Ikiyüzbininci Gece (1986), written at the request of one of the Jewish associations to be staged on the five hundredth anniversary of the Sephardic people seeking refuge in the Ottoman Empire. The play is about the traditions of Jewish culture, customs, inter-communal and inter-community relations, cultural values and historical events. İkiyüzbininci Gece presents the life of Jews in the Turkish lands against the background of historical events such as the First World War, Balkan Wars, fires and cholera. It reflects the fundamental conflicts of the Jewish Community, domestic and foreign events, in accordance with historical reality. In doing so, Bahar questions certain traditions and values in the fictional space in which she positions the historical events. ${ }^{32}$ While the themes of marriage, family relations, women and education are noticeable, how these events are fictionalized carries the author's questioning point of view.

The play contains 4 parts, each connected with a city and consisting of different episodes. The first part is set in Ankara during the First World War and the $16^{\text {th }}$ century. In the first scene, which is set during the First World War, the economic difficulties, drought and livelihood

32 Ibid., 176. 
problems of the Jews are depicted. Haymaçi, who does not understand that Aron wants to borrow his donkey Mercedes, thinks Aron wants his daughter instead of his donkey, and events develop because of this misunderstanding. In the second episode, Jewish women preparing winter provisions together give information about the Purim Festival. In the third episode, a play about the "blood libel"33 is performed in the courtyard of the boys' school in Ankara in honor of the Purim Festival and the audience learns about the events in the $16^{\text {th }}$ century through another play fictionalized in the play. The next three episodes are set in a Jewish neighborhood in the $16^{\text {th }}$ century and provide information about the blood libel incidents of the time. Part two takes place in Bursa immediately after the Balkan War. Jewish marriage, involving the asking for a girl, and wedding traditions are introduced through the events that unfold on the axis of two young people named Yuda and Korin, who fall in love. The third part begins with the actors rushing through the stage, fleeing from the fire and cholera disasters in Edirne in the $19^{\text {th }}$ century. After these time jumps, a woman remaining on stage says she is waiting for her husband's return, who has gone to the Balkan War. The first episode ends with a happy ending as her husband returns from the war. The next three episodes deal with the drama of 13-year-old Ester, who is married off to her late sister's widowed husband, so that the newborn baby of Sarah Kanetti, who died at a young age, will not go to a random stepmother. In Part 4, the author takes her readers to Istanbul. First, the Jews are mentioned who lived in Hasköy, Balat and Fener at the beginning of the $20^{\text {th }}$ century. The actors speak half Turkish, half French. In the second episode, we learn that with the change in the social life of Jews in Istanbul in the 1930s, Hasköy and Balat lost their former popularity and now all shop in Pera. While the presenter tries to show the audience the modern Pera, he accidentally goes to the Byzantine era. In Pera, the city's tannery during the Byzantine Period, his wife abandons a man dealing with leather because of the unpleasant smell that permeates him. As the presenter tries to go to Pera in the 1930s, there is another time slip, and with it the readers learn about the Jews that contributed to Ottoman cultural life from the ghosts of the Nahmias family who brought the printing press to the Ottoman Empire in the $16^{\text {th }}$ century. In the last scene, a Jewish family that owns a shop in Mahmutpaşa, the commercial center of Istanbul, search for a suitable groom.

All the stories in this play are based on historical events. The spaces where the author introduces a critical approach are visible as the narratives and dialogues, in which she predicts how individual stories of the past might have occurred, as well as in the conflicts between the perspectives of the characters. Some stories and characters are based on Bahar's own family. In her memoir, she points out that the Edirne part of the play is based on the life story of her grandmother and great-great-grandfather, the poet Natan Malki, and his family. Moşe, a young

33 Allegations of the "Needle Barrel" or the "Blood Libel" are a myth that Jews put the blood of Christian or Muslim children in the bread they bake on Passover. It has been repeated from time to time since the $1^{\text {st }}$ century with similar stories in different eras. In late 1553 or 1554, Suleiman the Magnificent issued an edict officially stating that blood libels against Jews were null and void. 
soldier whose legs froze at the front during World War I and were therefore amputated, is indeed her mother's uncle. ${ }^{34}$

Overall, the play is in line with the general discourse of tolerance and gratitude that characterizes the political discourse of the Jewish community in Turkey. However, as an individual, she does not see everything through rose-colored glasses deviating from the general trend, and this is visible in the play. She points out this discrepancy in the play's preface:

Contrary to the wishes of those who expected a play that begins in Balat, Hasköy, ends in Beyoğlu and Şişli, in which the women sing while hanging the laundry, and who refused to stage it that way after they read the draft during the first rehearsal and were surprised, I have finished it according to my heart's desire with a little editing. I apologize to them. ${ }^{35}$

\section{An Analysis Through the Texts}

Bahar's plays put on trial all the concepts around her fragmented subjectivity from a historical point of view; her reckoning with her personal past and the history of the society she lives in merge. She firmly believes that one must know and question their past and origin and accept it to be a part of a future. In Senyora she has Beatrice speak on her behalf: "Those who do not know the past cannot understand the present. ${ }^{36}$ Similar remarks come from Pudu Hepa the Hittite Queen, in Ölümsüz Kullar; "One cannot win a war that's cause is unknown." "History is nothing but a repetition of itself through time. " 38 Whilst memory is crucial for a society to have an identity, traditions are bridges that connect the present to the past as Flavius' mentor in Demokles 'in Kılıcı illustrates:

BANNUS- The important thing is that we stick to each other and hold on to our traditions, customs, beliefs, language, and value judgments... Not to deviate from them... As long as we can protect them and pass them on from generation to generation, we will live forever as a unique part of the colorful mosaic that makes up the world and will not disappear. ${ }^{39}$

Moreover, in the preface to her play İkiyüzbininci Gece $^{40}$, Bahar, asks and answers the very simple but historically charged question; "who is a Jew?" In the precise way that she asks as can be seen below, the nuance already conveys her perspective; since she structures

34 Bahar, Oradan Buradan: Altmış Yılın Ardından, 80-81.

35 Beki L. Bahar, İkiyüzbininci Gece: Müzikal Oyun: IV bölüm. (İstanbul: B.L. Bahar, 1986), 3.

36 Bahar, Toplu Oyunları 1, 69.

37 Ibid., 23.

38 Ibid., 25.

39 Beki Luiza Bahar, Demokles 'in Kılıcı Flavius ile Demokles (İstanbul: Mitos Boyut Yayınları, 2004$), 19$.

40 The play was written to be performed to celebrate the $500^{\text {th }}$ anniversary of the arrival of the Jews in Ottoman lands after their expulsion from the Iberian continent in 1492. Here it must be noted that there were Jews in these lands before this event and Bahar expresses this fact on all occasions. In fact, the number of nights (two hundred thousand) in the title of this piece indicates that the Jews have lived in these lands for more than 500 years. 
her question within a historical framework. "Who is a Jew who has been in existence since the unknown ages of history?"41 When one studies this quote closely, it is evident that Bahar places the Jewish society in a historical context through which she constructs an idea of identity that is built up as a result of historical events. The trap here is that history itself is often institutionalized and politicized and can never be objective. But she shows she is aware of this. In the introduction to Demokles 'in Kllıcı she questions:

Can historians be objective? Someone who is praised to the heavens by one is referred to as "mad" by another one. Be that as it may, the people of the country demand its historians to glorify their ancestors and fill the pages of history with heroic epics. ${ }^{42}$

This quote elucidates that she is critical towards historical narratives and discourses and is an advocate of a more analytical analysis of the past. Bahar is clearly fond of Ellis Rivkin, a historian well known for his acute analysis of the interrelationships between Jewish life and that of the surrounding culture and his application of innovative approaches to Jewish historical difficulties. His reconstruction of the Pharisees' dilemma and his idea of the "unity principle," which he considers as the primary constant in Jewish history, are the most wellknown of these approaches. He believes that the Jewish people have faced and understood catastrophic upheavals throughout history without losing their identity or aspirations. Bahar takes on Rivkin's understanding of historiography; the historical continuum is not random and therefore incomprehensible, but rather is an explainable process. According to Rivkin, history is not accidental, nor is it the result of unexpected processes. Instead, it is the outcome of events and forces that are comprehensible and thus responsive to rational and analytic explanation. ${ }^{43}$ Therefore, Bahar is after the analytic and rational explanations that cause events. In Senyora, she has her protagonist Beatrice explain the plausible reasons for Ottoman Sultan Suleiman saving her family from the Inquisition in Venice:

Suleiman the Magnificent risked a quarrel with the Pope and Venice by sending a special envoy to save us. He did this not only because the palace physician Hamon wanted it but also because of my fleet, which could sail far, my capitals, my great trading area, which included the whole of Europe. ${ }^{44}$

The same remark is also found in the play İkiyüzbininci Gece. Indeed, it is critical for Bahar to interpret the past via an analytical lens that considers economic, political, and social forces rather than from an emotive perspective that can lead to fanaticism and aversion to change. Even more so, in Demokles 'in Kllıcl, she places the past on trial in order to interrogate whether history's narration of the events or motivations of the individuals involved are accurate. Both

41 Bahar, Ikiyüzbininci Gece, 4.

42 Bahar, Demokles'in Kllıcı, 5.

43 David Ellenson, "Ellis Rivkin and the Problems of Pharisaic History: A Study in Historiography," Journal of the American Academy of Religion XLIII, no. 4 (1975): 788. https://doi.org/10.1093/jaarel/xliii.4.787

44 Bahar, Toplu Oyunlarl 1, 108. 
Flavius and Damocles are allowed to represent themselves, as the narratives surrounding their stories contain a great deal of hearsay.

She also criticizes suppressing one's identity by ignoring the past. The nurse's lines in Senyora are a typical example of Rifat Bali's explanation of Jewish society's use of the word 'kayadez' to silence those who dig into the past. Her protagonist, Beatrice, refuses to be silenced:

NURSE: Hush! It was Toledo; it was Roha. You play with the past, you always say what's on your mind. I don't have that problem with your sister Brianda.

BEATRICE: Enough! I'm tired of you shutting me up and comparing me to Brianda. Hush! Hush! Hush! Who doesn't know we fled Spain? ${ }^{45}$

This dialogue is an excellent example of navigating the dynamics at work in defining Bahar's identity. She weaves Nasi's journey of recognizing her origins and coming to terms with her Jewishness throughout the course of the play. The matter of descent is also discussed in Demokles 'in Kllıcı. Flavius is accused of betraying his heritage by praising a Roman Commander and his son, as well as by integrating into Roman culture. He denies these accusations. He responds to the first accusation by stating that he was merely being objective, and that this is not treachery. Furthermore, he speaks of integrating rather than assimilating, unquestionably a value held by the Jewish minority in Turkish society.

Bahar does not hold back from further criticizing the way Jewish society responds to adversity and conflict. She blames ignorance and conformism in particular as Beatrice's following line shows: "A society that defends itself against disasters by passive acts such as praying and fasting, and considers itself safe if it has three or five coins. " 46 Also, in the Edirne part of Íkiyüzbininci Gece, the head of the school admonishes the schoolteacher Bella for attempting to innovate within the confines of the conventional school play. In a conversation with her friend Ester ${ }^{47}$, she expresses her displeasure with this "don't let it out of the room" mentality. ${ }^{48}$ There is little doubt that Bahar uses this phrase intentionally, as it is a characteristic phrase popular in Jewish society in Turkey. From both examples, one can infer that she relates conflict avoidance with blind devotion to tradition. It should also be noted that she favors these two characters that, after being subjected to the roles that society has imposed on them as women, they decide to break free as individuals and determine their own fate. Having been married twice for practical reasons, Ester is in a love affair with a man who loves her only for love's sake, but has become the object of gossip because she flirts with him. Therefore, she leaves Edirne and starts an independent life as a woman in Istanbul. Bella, the teacher, also wants to

45 Ibid., 61.

46 Ibid., 118.

47 Ester is the character based on Bahar's grandmother.

48 Bahar, İkizyüzbininci Gece, 74. 
join her after her experience with the school principal. She wants to quit rather than get fired. This is a moving section of the play that strongly supports all the ideals that Bahar evidently holds dear as a woman. Independence, creativity, uniqueness, literacy...

Correspondingly, in Senyora, she emphasizes the individual's ability to choose his or her own destiny when Beatrice rebukes the nurse for attributing everything to fate: "You cling only to fate. Did you see? You changed your fate by moving to Portugal. "49 This question of deciding one's own fate as an independent individual vs. society's expectations is a conflict that Bahar certainly cares about. In fact, a sentimental piece is in her memoir where she writes about Berta, a woman she knew as a little girl who was her aunt's neighbor. Berta was a young woman without a drachma and lived with her brother, a bus driver. One night Berta disappears and everyone assumes someone has kidnapped her. By contrast, Bahar and her cousin recall seeing her in the past with a man with whom she was talking discreetly in the garden late at night. After some time, it turns out that she had run away with the driver, who wasn't Jewish. A few years later, news of her death arrives. Bahar is perplexed and cannot decide whether Berta pursued love with her own free will or had to settle for what she could find since neither her life with her brother's family was great, nor did she have a promising future. Even years later, when she writes about Berta in her memoirs, she confesses she cannot reconcile the story of Berta in her conscience. ${ }^{50}$

But it is not only individualism that Bahar problematizes in these instances. These characters have one thing in common: being women. There is an ache in Bahar's heart since she herself had to make certain choices as a woman, giving up her deepest desires. The following stanza from one of her poems, Dişi Özlemi (The Aching Female), is obviously about these longings:

\author{
Without answering to anyone \\ as if she were a warrior \\ and then, as a saint, \\ if she could forget her femininity, \\ seeing herself as equal to Adam \\ and feel and live her personality, only her personality... ${ }^{51}$
}

In Ölümsüz Kullar, she portrays the protagonist as a woman who has forgotten her femininity and is equal to her husband. This quality is shown as both a defect and strength as the character reconciles her understanding of being a woman throughout the play. One quality that the author absolutely favors is the literacy of this woman. This is obvious in the scene where Pudu Hepa studies the tablets to discover the cause of the epidemic. On another note, her dedication to her responsibilities as queen causes her to lose sight of her femininity and to neglect her husband.

49 Bahar, Toplu Oyunlart 1, 63.

50 Bahar, Oradan Buradan: Altmış Yılın Ardından, 23-30.

51 Beki L. Bahar, Kişi Bunalımı + Dişi Bunalımı (Ankara: Ayyıldız Matbaası, 1970), 13. 
Whereas the husband's mistress is presented as attractive but quite ignorant. She concludes that an ideal woman must have both qualities. ${ }^{52}$ Nonetheless, she also expresses that it is a dilemma. This can be presumed from her advice to the mistress Haştayar, who wants to know how to become enlightened through knowledge. Pudu Hepa replies:

One cannot have what one desires so easily and quickly. You must go through sleepless nights. And this will cause you to lose many things. It will rob you of your beanty. You will have a hunchback because you read so much, and your eyes will become unhealed, your reflection will wither, and your lips will change color. ${ }^{53}$

In this quote, she portrays a woman who dedicates herself to knowledge and society neglecting the society's expectations of femininity from a woman. This theme also echoes in her poem, The Aching Female, and it is expressed as the wish of a woman to fully embrace her real self, stripped of her femininity. However, as is seen in Ölümsüz Kullar, the society's expectations and the author's perspective is also inextricably linked causing an unresolved tension between the person's self-perception and desires and the discourses developed by society that the author also has naturally adopted.

Craig Calhoun's, discussion of the issues of identity in connection to the recognition problem to demonstrate that the matter of recognition is essential to any reflexivity help to illuminate this point:

We face problems of recognition because socially sustained discourses about who it is possible, or appropriate, or valuable to be inevitably shape the way we look at and constitute ourselves with varying degrees of agonism and tension. ${ }^{54}$

It could be argued that for Bahar, the degree of agonism and tension caused by this problem in relation to conceptions of being a woman was quiet high and unresolved as is for the women in Pudu Hepa. In an interview where she tells the story of getting married to her husband, this unresolved conflict is reverberated:

The young man is staring at me. He is free to look as much as he wants! I used to be a tough girl. "What an elegant dress, it fits so well." "What's it for you?" I replied. I was a grumpy girl. But I knew he liked me, and I wasn't indifferent about it. Then someone else follows me around a lot; I get engaged reluctantly, then I break up with him. When he (my husband) finds out, he contacts my father. "I'd like to speak with you about a job, " he says to my father. It never occurs to my father, and he says, "Don't come to me; I'll come to you." Anyway, when they meet, he says in the Jewish manner, "I want Beki's hand." My father is a shy man as well. He leaves the store without saying yes or no. He returns home and informs my mother. As I am preparing for the law exams, my father says, "Let's not say anything;

52 Bahar, Toplu Oyunları 1, 36-37.

53 Ibid., 37.

54 Craig Calhoun, Social Theory and the Politics of Identity (Malden, Mass: Blackwell, 2003), 20. 
now the girl is busy with the exam, let's not worry her". Will my mother relent? A husband is hard to find among us Jews, and there is the issue of money, which is customarily given from the girl's side, known as dowry. It was difficult to find a husband at the time. "How much money will this man want from us?" my father asks. Myself: "He would have put a man in the middle if he wanted money. Why be concerned about the drachma?" My father stated, "Is it free? What a pity!" I become enraged and say, "Dad, you won't give money." You call or send a man, you say yes, and you never discuss money. Do you understand me, dad? Nobody here says, "I want your daughter!" A man gets put in the middle, the man talks to him, and there's a bargain... My father finds a man and says, "Tell him I'll give him 3,000." "Thank you very much," he says. That is how we met and married. ${ }^{55}$

As can be seen, she resists being treated as a commodity as the society expects her to be. The same manner is seen in Beatrice's initial refusal when Don Francisco asks from her brother her hand in marriage. It is almost a reenactment of Bahar's experience as a young girl:

That night, I forgot the rules of propriety that a young girl must follow. It was a pleasure to chat with Don Francisco. His answers and knowledge amazed me, and I listened to him without hiding my feelings. (Smiles meaningfully) He considers me a quiet, docile person who will look at him with admiration, listen to him, flatter him, and make him happy all his life. (Seriously) Give my thanks. If I need a library, I will consider it." ${ }^{6}$

This is the final and best possible example on the intimate manner in which she deals with the problems of identity as with other issues related to her experiences and understanding of selfhood. The themes and concepts in Bahar's plays are built around these experiences. Tracing these themes and concepts in her texts clarifies how Bahar negotiates her minority subjectivity in relation to writing.

\section{Conclusion}

Consequently, although there are unresolved issues and Beki Luiza Bahar's self is reflected in her texts as fragmented between the desires of the individual and the society, a struggle for identification and recognition is observable in the texts. Therefore, her playwriting can be described as a constant mediation between the contexts that define her identity; it is a search for subjectivity. The themes and concepts of memory, history, individualism, society, tradition, being a woman, independence and knowledge accompany this search that she voices in an intimate manner.

On a final note, considering the fact that she is the first published Turkish-Jewish woman playwright, theatre artists have paid little attention to her so far, an unfortunate fact that confirms the title of her memoir. One of the aims of this research was to demonstrate how valuable her works are as cultural products that reveal a society's fundamental dynamics.

55 Türkoğlu, Kutluata, and Bahar, "Türkiye'de Yahudi Olmak", 40.

56 Bahar, Toplu Oyunlarl 1, 66. 
Peer-review: Externally peer-reviewed.

Conflict of Interest: The author has no conflict of interest to declare.

Grant Support: The author declared that this study has received no financial support.

Hakem Değerlendirmesi: Dış bağımsız.

Çıkar Çatışması: Yazar çıkar çatışması bildirmemiştir.

Finansal Destek: Yazar bu çalıșma için finansal destek almadığını beyan etmiștir.

\section{BIBLIOGRAPHY / KAYNAKÇA}

Bahar, Beki L. Demokles 'in Kılıcı: Flavius ile Demokles: İki Bölüm. İstanbul: Mitos-Boyut, 2004.

Bahar, Beki L. İkiyüzbininci Gece: Müzikal Oyun: IV Bölüm. İstanbul: B.L. Bahar, 1986.

Bahar, Beki L. Kişi Bunalımı + Dişi Bunalımı. Ankara: B.L. Bahar, 1970.

Bahar, Beki L. Oradan Buradan: Ne Kendi Tanır, Ne De Söz Edeni Vardır. İstanbul: Gözlem Gazetecilik Basin ve Yayın, 2000.

Bahar, Beki L. Ordan Burdan: Altmış Yılın Ardından. İstanbul: Gözlem Gazetecilik Basın ve Yayın, 1995.

Bahar, Beki L. Toplu Oyunları 1: Ölümsüz Kullar ; Senyora ; Alabora. Istanbul: Mitos-Boyut, 2005.

Bali, Rifat. "Politics of Turkification in the Single Party Period". Swiss Society for Middle Eastern and Islamic Studies, Basel, Switzerland, 14-16 October 2004.

Brubaker, Rogers, and Frederick Cooper. "Beyond 'Identity."” Theory and Society 29, no. 1 (February 2000): $1-47$.

Calhoun, Craig. Social Theory and the Politics of Identity. Malden, Mass: Blackwell, 2003.

Ellenson, David. "Ellis Rivkin and the Problems of Pharisaic History: A Study in Historiography." Journal of the American Academy of Religion XLIII, no. 4 (December 1975): 787-802. https://doi.org/10.1093/ jaarel/xliii.4.787.

Esen, Uluç, Selim Hubeş, İzzet Bana, Rivka Bihar and Ömer Faruk Kurhan. "Panel: Beki L. Bahar Tiyatrosu." In MIMESIS Tiyatro Çeviri/Araştırma Dergisi 19, edited by Ayşan Sönmez, 19:236-62. March, 2009.

Hadar, Gila. “Turkey: Ottoman and Post Ottoman.” Jewish Women’s Archive. Accessed July 6, 2021. https:// jwa.org/encyclopedia/article/turkey-ottoman-and-post-ottoman.

Hayim, Beti. “The Sense Of Self, Superego And Ego-Ideal In Turkish Sephardic Jewish Young Adults,” 2009.

Lejeune, Philippe. On Autobiography. Edited by Paul John Eakin. Translated by Katherine Leary. Minneapolis: Univ. of Minnesota Press, 1995.

Özmen, Emre. “Beki L. Bahar’1n Tiyatro Eserlerinde Sefarad Dünyas1,” 2010.

Saral, Sevilay. “Beki L. Bahar'ın Ardından .” MİMESİS Tiyatro Çeviri/Araştırma Dergisi 19 (March 2012): $227-34$

Türkoğlu, Gülriz, Zeynep Kutluata, and Beki Luiza Bahar. Türkiye’de Yahudi Olmak: Beki Bahar ile Söyleşi. Interview. Kültür ve Siyasette Feminist Yaklaşımlar 7, March 2009.

Ulusoy Tunçel, Ayşe. “Beki L. Bahar'ın Oyunları ve Oyun Yazarlığı ." MíMESIS Tiyatro Çeviri/Araştırma Dergisi 13 (March 2007): 95-138.

Tischler, Ulrike, and Rifat Bali. "The Alternative Way to Come to Terms with Past. Those Who Try to Forget: Turkey’s Jewish Minority.” Essay. In From “Milieu De mémoire” to "Lieu De mémoire” The Cultural 
Memory of Istanbul in the 20th Century, 100-110. München: Martin Meidenbauer, 2006.

Wagner-Egelhaaf, Martina. "Autobiography/Autofiction Across Disciplines.” Introduction. In Handbook of Autobiography/Autofiction, edited by Martina Wagner-Egelhaaf, 1-9. Berlin: De Gruyter, 2019.

Woolf, Virginia. The Death of the Moth and Other Essays. New York: Harcourt Brace \& Company, 1942. 
